\title{
Table of legislation and documentation of European Institutions
}

(chronological order)

REGULATIONS, DIRECTIVES, DECISIONS AND

RECOMMENDATIONS OF THE EUROPEAN

PARLIAMENT AND/OR THE COUNCIL

Directive 90/377/EEC of 29 June 1990 concerning a community procedure to improve the transparency of gas and electricity prices charged to industrial customers, O.J. 17.7.1990, L 185/16 .45

Directive 90/547/EEC of 29

October 1990 on the transit of electricity through transmission grids, O.J. 13.11.1990, L 313/30

Directive 96/92/EC of 19 December 1996 concerning common rules for the internal market in electricity, O.J. 30.1.1997, L $27 / 20$. $45,77,120,147$

Regulation 1/2003 of 16 December 2002 on the implementation of the rules on competition laid down in Article 81 and 82 of the Treaty, O.J. 4.1.2003, L 1/1...........47, 67, 68, 90, 92, 96, 102, 103-105, 172

Directive 2003/54/EC of 26 June 2003 concerning common rules for the internal market in electricity and repealing Directive 96/92/EC, O.J. 15.7.2003, L 176/37 ...... 45, 46, $60,93,120$

Regulation 1228/2003 of 26 June

2003 on conditions for access to the network for cross-border exchanges in electricity, O.J. 15.7.2003, L 176/1 .. 46, 59, 65, $111,112,114,116,120$, $122,143-145,147,172$

Regulation 1775/2005 of 28

September 2005 on conditions

for access to the natural gas transmission network, O.J.

3.11.2005, L 289/1

Directive 2005/89/EC of 18 January 2006 concerning measures to safeguard security of electricity supply and infrastructureinvestment, O.J. 4.2.2006, L 33/22 .90

Regulation $713 / 2009$ of 13 July 2009 establishing an Agency for the Cooperation of Energy Regulators, O.J. 14.8.2009, 
L 211/1 $47,57,60,61$, $68,103,144,164,172$

Regulation 714/2009 of the

European Parliament and the Council of 13 July 2009 on conditions for access to the network for cross-border exchanges in electricity, O.J. 14.8.2009, L 211/15 .46 $47,57,59,60,62$, $64,68,103,111,112$, $117,144,145,150,151$, $155,164,165,172$

Directive 2009/72/EC of 13 July 2009 concerning common rules for the internal market in electricity and repealing Directive 2003/54/EC, O.J. 14.08.2009, L 211/55 ....46, 47, $57,59,60,68$, $103,145,164,172$

Regulation 1227/2011 of 25

October 2011 on wholesale energy market integrity and transparency, O.J. 08.12.2011,

L 326/1 47

\section{REGULATIONS,} DIRECTIVES AND DECISIONS OF THE EUROPEAN COMMISSION

Regulation 2790/1999 of 22

December 1999 on the application of Article 81(3) of the Treaty to categories of vertical agreement and concerted practices, O.J. 29.12.1999, L 336/21. .77
Decision 2003/796/EC of 11

November 2003 on establishing the European Regulators Group for Electricity and Gas, O.J. 14.11.2003, L 296/34 59

Decision of 9 November 2006 amending the Annex to Regulation 1228/2003 on conditions for access to the network for cross-border exchange in electricity, O.J. 11.11.2006, L 312/59. 111-113, $115-117,122$, $133,138,172$

Regulation 330/2010 of 20 April 2010 on the application of Article 101(3) of the Treaty on the Functioning of the European Union to categories of vertical agreements and concerted practices, O.J., 23.4.2010, L 102/1 …....77, 80, $85-87,95,96$

NOTICES,

COMMUNICATIONS,

GUIDELINES AND OTHER DOCUMENTS OF THE EUROPEAN COMMISSION

XXIIIrd Report on Competition Policy (1993) ......................74

XXVIth Report on Competition

Policy (1996) 74,75

Notice on the application of the competition rules to access agreements in the telecommunication sector, O.J. 22.8.1998, C 265/2 ....131, 133 
XXXth Report on Competition

Policy (2000) .75

Guidelines on the applicability of

Article 81 EC to horizontal cooperation agreements, O.J. 27.4.2000, C 118/3 .80

Guidelines on vertical restraints, O.J. 13.10.2000, C 291/1......78

Notice on agreements of minor importance which do not appreciably restrict competition under Article 81(1) of the Treaty (de minimis), O.J. 22.12.2001, C 368/13 80,99

XXXIInd Report on Competition Policy (2002). 75,85

XXXIIIrd Report on Competition Policy (2003). 118

DG Energy, Note of Interpretation on Directives 2003/54-55 and Regulation 1228/03 in the electricity and gas internal market: exemptions from certain provisions of the third party access regime of 30.1.2004. $146,151,156$

Guidelines on the application of Article 81(3) of the Treaty, O.J. 27.4.2004, C 101/97 ......78, 88, $95,96,173$

Draft inter-institutional agreement on the operating framework for the European regulatory agencies, $\operatorname{COM}(2005) 59$ final of 25.2.2005 60

Staff Working Paper on the Decision C-17/03 of 7 June 2005 of the Court of Justice of the European Communities, SEC(2006) 547 of 26.4.2006 120
Communication on the methodology for analysing State Aid linked to stranded costs, O.J. 25.5.2006,

L 139/1. 77,119

Communication, An Energy Policy for Europe, COM(2007) 1 final of 10.1.2007 60

Communication, Prospects for the Internal Gas and Electricity Market, $\operatorname{COM}$ (2006) 841 final of 10.1.2007. 60

DG Competition, Report on Energy Sector Inquiry, SEC(2006) 1724 final of 10.01.2007 ...1, 3, $5,29,44,47-52,60,66$, $75,84,93,95,98,110$, $113,114,116,122$, $129,131,138,170$

Report on progress in creating the internal energy market, $\operatorname{COM}(2008) 192$ final of 15.4.2008 47

Working Paper accompanying the Report on the functioning of Regulation 1/2003, SEC(2009) final of 29.4.2009 .92

DG Energy, Commission Staff Working Document on Article 22 of Directive 2003/55/EC concerning common rules for the internal energy market in natural gas and Article 7 of Regulation (EC) No 1228/2003 on conditions for access to the network for cross-border exchanges in electricity - new infrastructure exemptions, SEC(2009) 642 final of 6.5.2009 ....144, 155, 157, 160, 162,164 
Guidelines on vertical restraints, O.J. 19.05.2010, C 130/1 ....78, $80,86,87,95,96$
Communication, Making the Internal Energy Market Work, of 15 November 2012 , COM(2012) 663 final .47 